\title{
Foreword
}

\section{Special Issue: Constitution-making and political settlements in times of transition}

\author{
C H R I S T I N E B E L L \\ School of Law, University of Edinburgh, Old College, South Bridge, Edinburgh EH8 9YL
}

Email: christine.bell@ed.ac.uk

In this special issue we consider how constitutional design and adjudication must be understood to have a specific political role in constructing and enabling a political settlement. We understand the political settlement to be the shared understandings as to how power is to be held and exercised that forms the political constitution which the constitution attempts to institutionalise. We collectively argue that traditional constitutional devices have to be understood as operating differently in times of transition where the constitution plays a very constructivist role with respect to the forming of agreement, rather than reflecting prior agreement.

\section{Acknowledgements}

This special issue is an output of the Political Settlements Research Programme-PSRP (www.politicalsettlements.org). The PSRP is supported by funding from the Department of International Development, United Kingdom. Nothing herein constitutes the views of the Department, or has been subject to input by the Department. 